\section{Centocor's better EPO mimetic}

\section{By Lauren Martz, Staff Writer}

Researchers at Maine Medical Center Research Institute have shown that Centocor Inc.'s CNTO 530 erythropoietin mimetic could offer better safety and efficacy, together with less-frequent dosing, than erythropoietin drugs on the market. ${ }^{1}$

In a paper published in Blood, stem cell biology program director Don Wojchowski and colleagues at the institute reported that CNT0 530 , a dimeric erythropoietin (EPO) mimetic peptide fused to a human IgG4 Fc scaffold, could cause a larger and more persistent increase in erythropoiesis than marketed erythropoiesis-stimulating agents (ESAs). The compound works by stimulating the formation of erythroblasts and expanding the erythroid progenitor pool within bone marrow.

The team compared the effects of CNTO 530 with two EPO drugs that are approved to treat various forms of anemia-epoetin alfa and darbepoetin alfa. Amgen Inc. markets Aranesp darbepoetin alfa and Epogen epoetin alfa, whereas Centocor's parent, Johnson \& Johnson, sells Procrit epoetin alfa.

A single dose of CNTO 530 increased hematocrit for up to 25 days in mice, whereas the effects of epoetin and darbepoietin persisted for 10-12 days. This suggested that CNTO 530 could offer sustained effects and require fewer treatments than the marketed drugs.

Anatole Besarab, a member of the scientific advisory board at Medgenics Inc., said CNTO 530's structure allows it to circulate for a long time. Medgenics' Epodure, a transdermal biopump implant device that delivers EPO, is in Phase I/II testing to treat anemia associated with chronic kidney disease (CKD).

In mouse models of chemotherapy-induced anemia, CNTO 530 significantly lowered anemia severity compared with that seen using darbepoietin.

According to Wojchowski, "the next most likely steps for CNTO 530 are clinical trials."

"Phase I has been completed with good success in using a predecessor compound,CNTO 528," he told SciBX. "CNTO 530 is a superior-acting compound that appears to show better efficacy at stimulating red blood cell production, so it would next be taken through clinical testing."

Wojchowski said the institute ran the study under a sponsored research program with Centocor.

Despite CNTO 530's favorable in vivo results, some researchers contacted by SciBX said the compound may be too late to the party.

Jay Wish, professor of medicine at Case Western Reserve University and a nephrologist at University Hospitals in Cleveland, noted that the competition is already much further along. He said a case in point is Affymax Inc.'s Hematide, which, like CNTO 530, is a peptide mimetic without recombinant EPO homology.

Hematide is in Phase III testing for anemia, with results expected in early 2010. Phase II data showed the compound's erythropoietic effects lasted for one month.

"Developers of CNTO 530 will have to consider whether there's enough clinical superiority of their drug and enough market share left," Wish said.

Affymax declined to comment.

Another unanswered question is whether CNTO 530 can avoid the safety issues that have plagued the marketed ESAs. The risks of ESAs include cardiovascular events such as thromboembolism, particularly with higher doses, that can increase mortality. ${ }^{2}$

"There are a number of safety issues associated with ESAs as a class, most of which have been observed in patients requiring higher doses and/or achieving hemoglobin levels $>13$," Wish noted.

Although clinical studies will be necessary to determine whether CNTO 530 carries the same risks as the marketed ESAs, Wojchowski said the compound is unlikely to have immunogenicity issues.

"There aren't a lot of safety issues with the humanized IgG4 Fc backbone, so it should not be an issue," he said.

Wojchowski also noted that CNTO 530 has no homology to EPO. This is potentially beneficial, he said, "because when EPO is given, patients can develop antibodies even though it matches their endogenous proteins. Such antibodies can cause long-term complications because they can continue to react with endogenous EPO."

According to Wojchowski, CNTO 530 has been patented by the pharma company and is available for partnering with Centocor.

The company did not comment on the development or partnering status of CNTO 530 and CNTO 528.

Martz, L. SciBX 2(12); doi:10.1038/scibx.2009.475

Published online March 26, 2009

\section{REFERENCES}

1. Sathyanarayana, P. et al. Blood; published online March 5, 2009; doi:10.1182/blood-2008-08-172320

Contact: Don M. Wojchowski, Maine Medical Center Research Institute, Scarborough, Maine

e-mail: wojchd@mmc.org

2. Edelson, S. BioCentury 15(12), A1; March 12, 2007

COMPANIES AND INSTITUTIONS MENTIONED

Affymax Inc. (NASDAQ:AFFY), Palo Alto, Calif.

Amgen Inc. (NASDAQ:AMGN), Thousand Oaks, Calif.

Case Western Reserve University, Cleveland, Ohio

Centocor Inc. (NASDAQ:CNTO), Malvern, Pa.

Johnson \& Johnson (NYSE:JNJ), New Brunswick, N.J.

Maine Medical Center Research Institute, Scarborough, Maine

Medgenics Inc. (LSE:MEDG), Vienna, Va.

University Hospitals in Cleveland, Cleveland, Ohio 